\title{
Dayah Ruhul Falah Samahani Education System Aceh Besar District
}

\author{
Yusran $^{1}$, Kasuwi Saiban', Zainur Rozikin² \\ ${ }^{1}$ Doctoral Program in Social Science, University of Merdeka Malang, Indonesia \\ ${ }^{2}$ Lecturer in University of Merdeka Malang, Indonesia \\ yusran_02@yahoo.com
}

\begin{abstract}
To achieve this goal, it is necessary to have an integrated education system implemented by several Acehnese Islamic boarding schools so that students have various life skills, are creative, independent, and become noble citizens. From this description, the traditional education system in Aceh has experienced very drastic changes, and these changes are still continuing because the shape and education system are still felt to have not met the expectations of the public. Dayah Ruhul Falah Samahani's education system has also undergone changes by integrating the curriculum in accordance with the general education system with the aim of giving birth to a generation that can master Imtaq and Science and Technology, so that Dayah Ruhul Falah Samahani becomes an alternative for the community to make a place to educate their children. The research method used in this study is a qualitative method. Through qualitative methods researchers want to gain an understanding and deep thought about social reality and facts that are relevant to changes in the Dayah education system. In line with the above purpose, Creswell (2010) suggests that qualitative research is "methods for exploring and understanding the meaning that some individuals or groups of people ascribe to social or humanitarian problems". Data collection is done through observation, interviews and document review. As for the internal obstacle in the change in Dayah education system, it is caused by the first factor of the family of Dayah leaders who are still less supportive and also some of the Dayah teachers who are still difficult to accept changes. Furthermore external constraints relate to the perception of other Dayah leaders who are negative and there is no longer any contribution either from the staff or the budget from the community.
\end{abstract}

Keywords

Dayah; educational system change

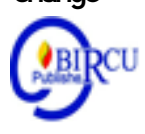

\section{Introduction}

Education basically functions to develop abilities and shape character and civilization in the context of educating the life of the nation with the aim of developing the potential of students to become human beings of faith and to fear God Almighty, knowledgeable, have various life skills, be creative, be independent, and become citizens with noble morals. Therefore, part education is a shared responsibility between parents, the community and the government. 
The implementation of education is an activity of implementing the education system component in the path, level and type of education so that the education process can take place in accordance with the objectives of national education. Dayah education means conscious and planned efforts to realize learning facilities and learning processes so that students actively develop their potential to have spiritual strength, self-control, personality, intelligence, noble character and the skills needed by themselves, society and the state in accordance with Islamic teachings. Dayah as one of the places to study and a place to develop knowledge is one of the determining factors and very influential in the development of science.

Through Dayah education can give birth to generations who have the character to receive the mandate of the nation's leadership. Yusuf stated that "Education is a conscious effort of the older generation to transfer experience, knowledge, skills, educational formalities that are emphasized in Islamic education, and skills to their generation so that one day they will become men of Allah." The existence of Dayah educational institutions as a place and means to educate and equip people to become virtuous human beings is needed in an effort to form mindsets.

The government issued various policies to support the change in the education system in developing and empowering Dayah systematically, professionally and continuously, because the Aceh Government realized that the role and function of the Dayah was very large in religious education for the community, the Aceh Government and other Regency / City Governments in Aceh Province, has carried out various programs on Dayah institutions. The policy aims to improve and increase the quantity and quality of Dayah education.

After the Helsinki MoU, the government issued Law Number 11 Year 2006 concerning Aceh goverment which has the authority to carry out special features in the fields of religion, education, customs and the role of Ulama in determining regional policies. Furthermore, there is the Aceh Government Qanun Number 11 Year 2014 Regarding Education Organization, then Law Number 18 Year 2019 concerning pesantren was born. Dayah educational institutions have been able to produce scholars, Muslim scholars, community leaders, politicians and bureaucrats.

The process of organizing Dayah education in Aceh begins with the education system very democratically through Dayah institutions. Because Dayah education institutions live and develop heavily dependent on the wisdom of the community to manage them, they are the owners and the development of Dayah itself. Dayah education belongs to the community, so this educational institution integrates with people's lives, especially integrates with other religious institutions such as mosques, meunasah and other places of worship.

\section{Review of Literature}

\subsection{Concept of Dayah Education}

Dayah was the only official educational institution in Aceh at the time of the Sultanate of Aceh Darussalam. At that time the Islamic boarding school in almost every village was used as a place for children to learn, especially related to religion. Dayah is an inseparable part of Acehnese traditions. The existence of Dayah has a long history, deeply rooted in society, both in the pattern of social, cultural, and religious life. Dayah is also a traditional Islamic educational institution that teaches, understands, lives and practices religious teachings in daily life by emphasizing the importance of religious 
morals as a way of life in society. Dayah as the first and oldest educational institution for Muslims in Aceh and a place to study classical books.

Dayah education means conscious and planned efforts to realize learning facilities and learning processes so that students actively develop their potential to have spiritual spiritual strength, self-control, personality, intelligence, noble character and the skills needed by themselves, society and the state in accordance with Islamic teachings. Dayah is as an educational institution where students live in Dayah which focuses on Islamic education led by Tengku Dayah. Dayah education system consists of salafiyah and integrated, salafiyah system focuses on the implementation of Islamic religious education by using classical Arabic language and various sciences that support it while the integrated system is by integrating the school / madrasah curriculum with the salafiyah system based on life values that are the source on Islamic teachings.

Ruhul Falah Samahani Dayah education system in Aceh Besar District is a combination of religious education and general education that follows national education standards, so that community trust in integrated Dayah is very high. This belief certainly has an absolute truth value. With the combination of Islamic teachings and general education, it will shape the people's views so that they are always changing and developing in accordance with the changes and developments of the times encountered.

\subsection{Theories of Educational Sociology}

In the context of educational sociology, Dayah has a major contribution and contribute in giving birth to a generation that has the ability of science and technology and has faith and piety. The education system in Dayah by developing certain behavior patterns in accordance with what is expected in the Dayah and the prevailing norms. Dayah has the duty to convey a variety of knowledge to the new generation or students of both religious and general nature. In this case the Dayah teacher educates the students by conveying a certain amount of knowledge, attitudes, skills that are in accordance with the curriculum of the particular methods and control techniques that apply in the Dayah.

Dayah Ruhul Falah Samahani is an institution designed to teach the students (santri) under the supervision of a Dayah teacher, all students are required to stay overnight in a dormitory that has been provided to make it easier for learning interactions, supervision and to facilitate the achievement of goals. Education with regard to the development and changes in behavior of students. Education is related to the transmission of knowledge, attitudes, beliefs, skills and other aspects of behavior to the younger generation. Education that is applied to Dayah is a process of teaching and learning with patterns in accordance with community expectations. In teaching situations, it is the teacher who leads and takes full responsibility for the leadership that is carried out. He does not do the instructions and does not stand under the instruction of other human beings except himself, after entering the classroom situation. So after entering the class the task of Dayah teacher is as a leader and not merely controlling or criticizing.

\subsection{Educational Theory}

Education is basically an integral part of human life so it cannot be separated from the whole of human life. From the womb, born and during life, humans need education (long life education). Education plays an important role in the formation of the human person in relation to the development of individuals, groups, communities and nations. Educational theory seeks to explain how something happens and or is used in teaching 
and learning. Educational theory comes from the observation or experimental stage through a systematic method of the existing educational process. In other words, educational theory is a view or set of opinions related to education presented in a concept system. Educational theory is related to how an educational process is carried out, who is the target of education, in what way the educational process takes place, and how it is developed.

\subsection{Theories of Social Change}

Humans are individual beings who cannot escape from relationships with other humans, as a result of relationships that occur between individuals, humans give birth to social groups or become a society based on the similarities of interests. Basically every community in their lives will experience a change, which is called social change. The tendency for social change is a natural phenomenon that arises from the association of human life in society. Social changes will continue as long as there is still interaction between people and between communities.

In order to realize Dayah education system to equalize Dayah education with education that takes place nationally, Dayah education system referred to in this study means adjusting to the development and demands of the times. Therefore the change of the system is an effort to adjust by changing the structure, to make it a habit in accordance with the needs and desires of stakeholders. While the change in the education system in general is an improvement effort in the field of education. Changes in the education system have basic characteristics that are programmed and systemic.

Social changes related to the implementation of education proceed slowly because it is awaiting legalization from the Regional Government. This change basically rests on a change that requires a fairly lengthy process, in that process, there are several stages and agreements between the legislative and executive as procedural that must be passed to achieve the change that is in accordance with the wishes.

As for the causes and consequences of social change related to the first education system, community members have begun to shift from general education to Dayah education which is believed by the community to be both better and better. Both changes are considered part of the innovations that affect individual and group choices in Dayah education. Third, Dayah education system is considered to be very suitable both socially and culturally.

\section{Research Method}

In accordance with the research objectives set out in the previous section, the research method used to obtain valid and complete information relating to the implementation of the Dayah Education System is a qualitative method.

To get reliable information related to changes in the education system of Dayah Ruhul Falah Samahani, Aceh Besar Regency Post Implementation of Qanun Number 11 Year 2014 Regarding Education Organization, and related to supporting factors and inhibiting changes in Dayah education system, the researchers determined informants by purposive sampling with historical, academic, cultural and cultural considerations as well as structural positions that cling to the speakers. The informants selected by the researchers included 1 day Dayah Leadership, Aceh Besar 1 Dayah Education Office Head, 1 Aceh Besar District Education Council 1 person, 1 Ulama Consultative Council, 
Dayah Ulama Association 1 person, Dayah 2 Teacher, Qanun Originator Number 11 in 20142 people and 2 academics.

\section{Discussion}

To find out whether an educational institution is progressing or regressing, it is necessary to evaluate the learning model, curriculum and teaching and learning interactions applied. With the evaluation of educational actors can find out the obstacles and weaknesses they face. This evaluation is very important to know the ups and downs of an educational institution. Evaluation is an assessment of the progress, growth and development of students for educational purposes. Evaluation is also called an activity to determine the level of progress of an activity in Islamic education. This evaluation program is applied in order to determine the level of success of an educator in delivering subject matter, find weaknesses contained in it, both related to the material, methods, objectives, facilities, and so on. In this regard, the studies in this study are:

1. Ruhul Falah Samahani Dayah Education System in Aceh Besar District Post Implementation of Qanun Number 11 Year 2014 Regarding Education Implementation with indicators: Learning Model, Curriculum and Teaching and Learning Interactions. Changes in learning models and also changes in curriculum are often interpreted as a change towards the better, then the change means an improvement effort in accordance with the needs and developments of the times. Associated with changes in the education system, both regarding the learning model, curriculum and teaching and learning interactions in Dayah by combining classical and modern systems in the learning of the Qur'an and traditional books as well as on the pursuit of general subjects that have a humorous and paikem quality that is active learning, innovative, creative, effective and fun in integrating all general subjects with Islamic subjects. The results showed that the learning model applied by Dayah Ruhul Falah by integrating through providing Islamic illustrations in each learning curriculum so that by itself able to provide changes in subject matter as well as on the spirit of learning of students or students.

From the results of the study show that, there are several factors underlying the idea of changing learning models, curriculum and interactions in teaching and learning on Dayah, including the first, the history of the progress of Islamic education in the past. History records that the Islamic Ummah had experienced very rapid progress, especially in the field of science during the time of the caliph Al-Ma'mun of the Abbasids (167-218 H / 783-833 AD). Progress in the field of science means progress in education. This means that at that time experienced the advancement of education that covered various fields of science, both general and religious sciences. The progress of the Islamic ummah is marked by the emergence of Muslim scientists in various disciplines. The Islamic Ummah understands knowledge in a broad way not limited to the science of ritual worship, but rather covers all aspects of the life of the human race. Knowledge is studied and developed comprehensively not happened dichotomy of science. Likewise the caliphs paid great attention to the development of science.

Second, the Umayyad Dynasty in Andalusia (Spain), Spain was occupied by Muslims during the Caliph Al-Walid (705-715M), one of the Caliphs of the Umayyad Dynasty who was centered in Damascus. There are three names that are often called meritorious in the Spanish conquest, namely Musa bin Nushair, Tharif bin Malik and Tariq bin Ziyad. Of the three names, the last name is often called the most famous, because the army is bigger and 
the results are more real. His force consisted of a portion of the Barbarian tribe (Muslims from North Africa) supported by Musa bin Nushair and another part of the Arabs sent by AlWalid. His army of 7,000 people crossed the strait under the leadership of Tariq bin Ziyad. The Spanish army under the leadership of King Roderick can be conquered. Cordova fell in 711 AD, from there, areas of Spain, such as Toledo, Sevilla, Malaga, and Granada could be controlled easily.

During the Caliph Abdurrahman III who had the title An-Nasir. (912-1013 AD), this period Andalusians reached the peak of progress. This progress was made because of the development of science in all fields of philosophy, economics, medicine, agriculture, mining, architecture and so on. The Muslim scientists of Andalusi were so hungry for knowledge that the city of Andalusi could rival the progress of the Abbasid dynasty in Baghdad. Andalusi as the most advanced city in Europe in his day. When European leaders such as the leaders of the cities of Lyon, Nevar and Barcelona needed surgeons, engineers, architects, clothing tailors, musicians, they went straight to the city of Cordova.

Higher education began in the Al-Hakam II period. Institutions run by a group of professors. This higher education is centered in the cities of Cordova and Toledo. Both of these institutions attracted the attention of students from Europe to study in Cordova. Based on the above research results, it can be understood that the learning model, curriculum and educational interaction during the heyday of Islam in Andalusia were very advanced, not limited to practicing ritual worship alone. This is evidenced by many European young men studying at various universities in Andalusia. Arab society in Spain was a pioneer of civilization, culture and education, between the middle of the eighth century until the end of the thirteenth century. Through their efforts, ancient science and Islamic science were able to enter Europe. The Umayyads who were under al-Hakam's authority held teachings and had given many awards to scholars. He has built the "University" of Cardova alongside the Abdurrahman III mosque which subsequently grew into a well-known educational institution among the ranks of other higher education institutions in the world.

The University rivaled two other universities, namely Al-Azhar in Cairo and Nizamiyah in Baghdad, and has attracted the attention of students not only from Spain, but also from other places such as from European, African and Asian countries. During the caliph Abdurrahman An-Nashir founded the University of Cordova. Various fields of science studied at this university include: astronomy, geography, chemistry, mathematics, medicine, philosophy, law, history and so on. Students who have completed their studies at this tertiary institution will receive a diploma as proof of academic appreciation for scientists.

This is the inspiration for Dayah Ruhul Falah's leaders so they want to change the education system starting from implementing learning models, curriculum changes that are in accordance with the demands of the times and learning interactions that are different from before. Nowadays in learning, students' potential is explored and developed in accordance with the interests of their talents so that students are no longer directed to one uniform path, leaving many diverse paths. This means that Dayah graduates no longer focus solely on religious expertise, but these Dayah graduates have other skills that cannot be separated from religious values that have been instilled. The results show that with changes in learning models, curriculum and also interactions in learning, the learning process and atmosphere in Dayah Ruhul Falah is increasingly innovative, and graduates will also be able to continue their education in general majors. 
Based on the results of the study as described above, the learning model, curriculum and teaching and learning interactions in Dayah ruhul Falah Samahani can be described as the following diagram:

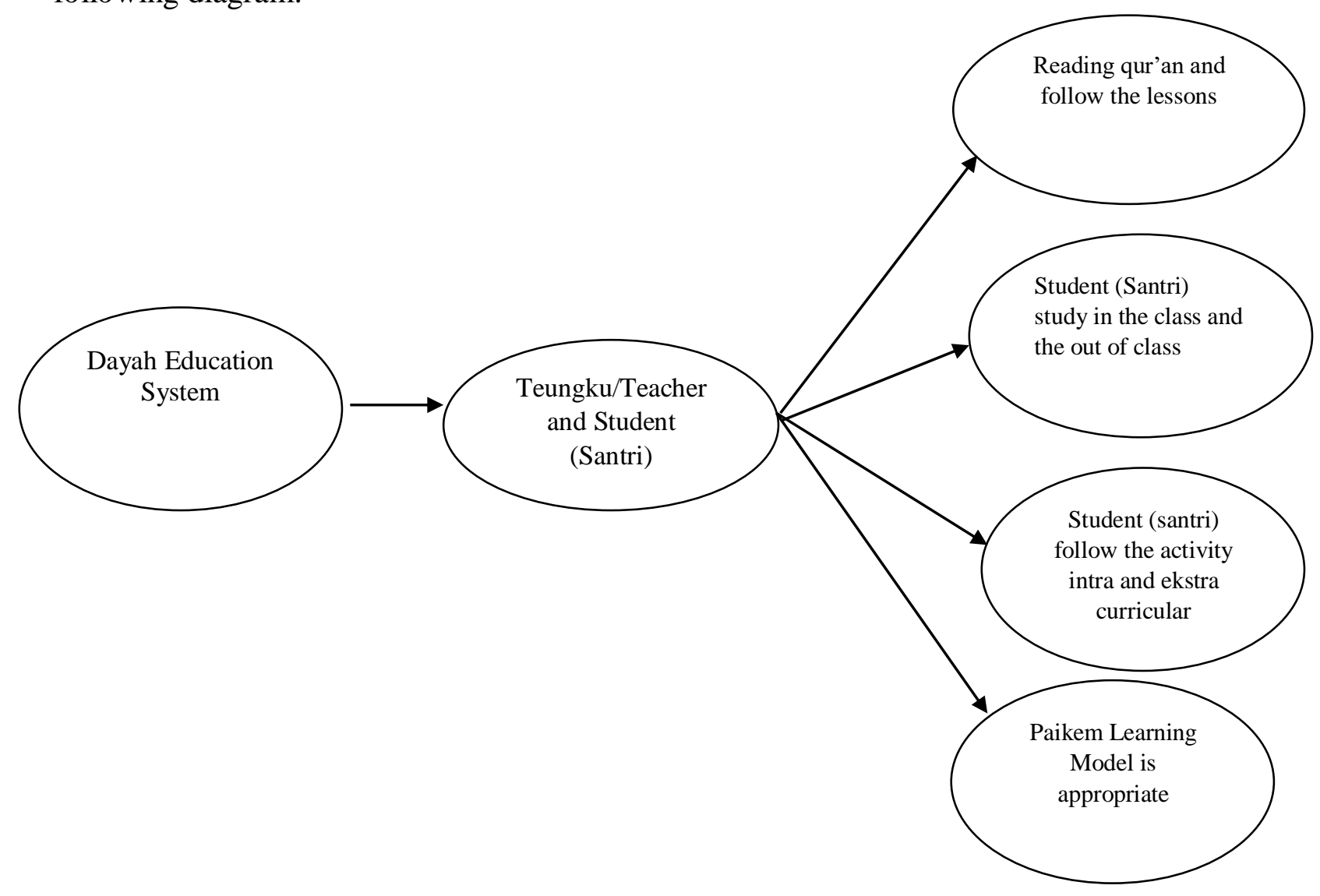

2. Supporting factors and obstacles to changes in the education system of Dayah Ruhul Falah Samahani District of Aceh Besar After the Implementation of Qanun Number 11 of 2014 concerning the Implementation of Education relating to several indicators including the first, Human Resources (HR). The results showed that the Ruhul Falah Dayah had good resources in developing the education system on the Dayah due to many Dayah teachers who had the ability to educate students and the existence of general subject teachers who had long served the Dayah. The results also show that the learning process is highly dependent on the quality of human resources, and human resources are largely determined by the science and education that is applied in Dayah. The better the quality of education, the more crowded the community will deliver their children so it has implications for the progress and prosperity of the Dayah. Then the second means and infrastructure. Dayah Dayah Ruhul Falah has various supporting facilities which are very adequate in developing the education system in the form of building facilities or study rooms as well as dormitories where students and students stay overnight, bearing in mind all students are required to live there. The results showed that facilities and infrastructure became one of the supporting factors in developing the education system in Dayah Ruhul Falah.

Furthermore, thirdly, there are various supports from the Regional Government as mandated by Qanun Number 11 of 2014 concerning the Implementation of Education. The 
results showed that, as for the form of support provided by the government to Dayah Ruhul Falah in the form of salaries for Dayah and also the salaries of teachers who taught at the Dayah and all Dayah teachers who met the requirements were allowed to take teacher certification as teachers teaching at public schools the other. The government also provides assistance in the form of additional facilities and infrastructure, mobile procurement and support in providing stationery and paper or stationery. The government also facilitates training of teachers who teach at the Dayah Ruhul Falah. Fourth, the community's enthusiasm indicator is quite encouraging, since the change in the education system of the Islamic boarding school the community's enthusiasm has increased and the Dayah has been made as an alternative by the community to choose it as a place for their children to study first and secondary education. However, in its implementation the researchers also found various factors that were obstacles in changing the Dayah Ruhul Falah's penididkan system including the first factors of Dayah leadership families who initially did not support changes in the penididkan system, resulting in different perceptions among the public. Did not get support for the change in the Dayah education system from the family due to the leadership of the Dayah being alumni of the traditional Dayah, so that they felt comfortable and integrated with the traditional Dayah and wanted to also develop the Dayah with the traditional learning system.

However, this was changed by the leader of the Dayah leadership with the argument that the Dayah education system needs to be adapted to the times and also to follow the technological advancements and finally based on a long discussion of the Dayah Ruhul Falah's education system changed and adjusted. Furthermore, the results of the study also showed that in the beginning there was a change in the education system in Dayah Ruhul Falah samahani, there was a different perception from other Dayahs who were not ready to accept changes in implementing or implementing Dayah education. The results showed that the perception of other Dayah leaders towards Dayah Ruhul Falah did not seem to maintain the habits that had been applied from generation to generation, instead they wanted to change the system. Nevertheless the results of the study show that Dayah Ruhul Falah remains committed to changing the education system in accordance with developments and needs, amidst the pros and cons, and believes in the legality of the government as well as the support as stated in Qanun Number 11 of 2014 concerning the implementation of education.

Thus Dayah Ruhul Falah Samahani unanimously and determinedly changed the education system and organized formal education at the first and advanced levels. The results also showed that, as long as there was a change in the education system of the Dayah, the community no longer participated in mutual cooperation or Dayah cleaning activities as they had done before, and that was also part of the inhibiting factor. In connection with this the Dayah Ruhul Falah manager conducted a cleaning of the Dayah environment by involving students who were also supported by the guardians of the students and it seemed that the educational facilities were cleaner than before because of the large number of students participating in maintaining environmental cleanliness.

\section{Conclusion}

For family members who accept the idea of a change in the Dayah penididkan system view all changes that occur in this world as sunnatullah that needs to be addressed wisely and wisely. Not all of these changes have a negative impact on humanity. Likewise with the change in the Dayah education system not to eliminate the characteristics of the authenticity 
of the Dayah. Undermining the education system implemented in Dayah aims to advance the oldest educational institutions in the archipelago. And they are also of the view that change is a necessity, bearing in mind the change and development of increasingly fast times. Changes in this era will be affected in every way, as well as education. It should not run away from this reality, but it must be able to exploit the changes and advancements of this age for the good and ease in advancing human civilization. With the change in the education system, Dayah education institutions have become more advanced, as have Dayah educational institutions before the Dutch war, where Dayah graduates can take part in all aspects of life, both government and private.

While family members who reject the idea of a change in the system of Dayah education argue that the system of Dayah education does not need to be changed because it will eliminate the characteristics of Dayah education itself. They reasoned to study a number of books that were required in Dayah not to be finished 5-10 years, they learned the book from morning, noon to night. Therefore, there are no time left for santri Dayah to take care of other matters including studying general knowledge. Likewise, the method applied so far is in accordance with the purpose of education in Dayah, namely to produce a cadre of scholars who continue the message of the Prophet Muhammad SAW. For this noble purpose the students must really explore religious knowledge, so they can master various laws in the religion of Islam.

\section{References}

Abdurrahman Saleh. 1993. Konsepsi dan Pengantar Dasar Pembaharuan Pendidikan Islam, Jajarta: DPP GUPPI,

Ahmad Tafsir. 1999. Ilmu Pendidikan Dalam Persfektif Islam, Bandung: Remaja Rosdakarya.

Arifin M. 1993. Ilmu Pendidikan Islam, Tinjauan Teoritis dan Praktis Berdasarkan Pendekatan Interdisipliner, Jakarta: Raja Grafindo Persada.

Hasyimi A. 1976. Pendidikan Islam di Aceh Dalam Perjalanan Sejarah, Sinar Darussalam, No. 63.

Ali Al-Jumbulati. 1994. Perbandingan Pendidikan Islam, Terj. H.M Arifin, dari judul asli Dirasah al-Muqaranah fi at-Tarbiyah al-Islamiyah, Jakarta: Rineka Cipta.

Amir Faisal Yusuf. 1995. Reorentasi Pendidikan Islam, Jakarta: Gema Insani Press.

Bustami A.Gani. 1970. Dasar-Dasar Pokok Pendidikan Islam, Jakarta: Bulan Bintang.

Ibnu Khaldum. 2005.Muqaddimah Ibnu Khaldum, Terj. Ahmadie Thaha, Jakarta: Pustaka Firdaus.

Nurkholish Madjid. 1997. Bilik-bilik Pesantren, Sebuah Potret Perjalanan, Jakarta: Paramadina.

Oemar Hamalik. 2009. Dasar-Dasar Pengembangan Kurikulum, Bandung: Remaja Rosdakarya.

Wiryokusumo Iskandar dan Usman Mulyadi. 1988. Dasar-Dasar Pengembangan Kurikulum, Jakarta: Bina Aksara. 